\title{
Alternative Splicing of MAPKs in the Regulation of Signaling Specificity
}

\author{
Galia Maik-Rachline, Inbal Wortzel and Rony Seger *(D) \\ Department of Biological Regulation, Weizmann Institute of Science, Rehovot IL-7610001, Israel; \\ galia.maik-rachline@weizmann.ac.il (G.M.-R.); inw2001@med.cornell.edu (I.W.) \\ * Correspondence: rony.seger@weizmann.ac.il; Tel.: +972-8-9343602
}

Citation: Maik-Rachline, G.; Wortzel, I.; Seger, R. Alternative Splicing of MAPKs in the Regulation of Signaling Specificity. Cells 2021, 10, 3466. https://doi.org/10.3390/ cells10123466

Academic Editors: Michael Cross and Stephen Yarwood

Received: 7 November 2021

Accepted: 1 December 2021

Published: 8 December 2021

Publisher's Note: MDPI stays neutral with regard to jurisdictional claims in published maps and institutional affiliations.

Copyright: (c) 2021 by the authors. Licensee MDPI, Basel, Switzerland. This article is an open access article distributed under the terms and conditions of the Creative Commons Attribution (CC BY) license (https:// creativecommons.org/licenses/by/ $4.0 /)$.

\begin{abstract}
The mitogen-activated protein kinase (MAPK) cascades transmit signals from extracellular stimuli to a variety of distinct cellular processes. The MAPKKs in each cascade specifically phosphorylate and activate their cognate MAPKs, indicating that this step funnels various signals into a seemingly linear pathway. Still, the effects of these cascades vary significantly, depending on the identity of the extracellular signals, which gives rise to proper outcomes. Therefore, it is clear that the specificity of the signals transmitted through the cascades is tightly regulated in order to secure the desired cell fate. Indeed, many regulatory components or processes that extend the specificity of the cascades have been identified. Here, we focus on a less discussed mechanism, that is, the role of distinct components in each tier of the cascade in extending the signaling specificity. We cover the role of distinct genes, and the alternatively spliced isoforms of MAPKKs and MAPKs, in the signaling specificity. The alternatively spliced MEK1b and ERK1c, which form an independent signaling route, are used as the main example. Unlike MEK1/2 and ERK1/2, this route's functions are limited, including mainly the regulation of mitotic Golgi fragmentation. The unique roles of the alternatively spliced isoforms indicate that these components play an essential role in determining the proper cell fate in response to distinct stimulations.
\end{abstract}

Keywords: MAPK; alternative splicing; ERK; JNK; p38; ERK1c

\section{Introduction}

Mitogen-activated protein kinases (MAPKs) are a group of signaling proteins that regulate almost all stimulated cellular processes, including proliferation, differentiation and stress response [1,2]. Dysregulation of these kinases is involved in many pathologies such as cancer, inflammation, developmental disorders and neurological diseases [3-6]. The signals to the MAPKs are transmitted via sequential phosphorylation and activation of protein kinases operating within a linear signaling cascade. Four such cascades have been identified thus far, and these are named according to the components of their MAPK tiers (Figure 1): (i) extracellular signal-regulated kinase 1/2 (ERK1/2, MAPK1/3 [7-10]); (ii) c-Jun-N-terminal kinase 1-3 ((JNK1-3, MAPK8/9/10 [11-13]); (iii) p38MAPK $\alpha-\delta((p 38 \alpha-$ $\delta$, MAPK14/11/12/13 [14-16]); and (iv) ERK5 (BMK1, MAPK7 [17,18]) cascades. While MAPK-like proteins such as ERK3/4, ERK7/8 exist as well, they are not considered as genuine MAPKs because of their distinct mode of regulation [19]. The MAPK cascades are all activated and transmit the signals of most extracellular stimuli to regulate the corresponding cellular processes. However, each cascade preferentially regulates some processes in which the other cascades play only minor functions. Thus, the ERK cascade preferentially regulates proliferation, differentiation and migration, p38 regulates mainly stress and immune responses, JNK preferentially regulates stress response and apoptosis, and ERK5 is mainly involved in stress response as well as proliferation. In pathologies, ERK is mainly involved in cancer, p38 in inflammation, and JNK in neurodegenerative diseases [3]. Although each of these seemingly linear cascades uses similar mechanisms to 
transmit their signals, their output is dramatically different in response to various stimuli. The initial specificity that determines cell fate is mediated by the MAPKK to MAPK tiers, but the cascades are tightly regulated by other means as well. Many specificitydictating processes have been identified [20] and widely reviewed including: (i) intensity and duration of the signals [21]; (ii) scaffolding interactions that bring components to close proximity and determine localization [22]; (iii) crosstalk with other signaling pathways [23]; (iv) substrate-related regulation [24]; and (v) dynamic subcellular localization of the MAPKs [25], which includes stimulated translocation [26,27]. However, the existence of different components in each tier of the cascades that may extend signaling specificity and functionality [1] has not been properly examined. These components are products of distinct genes, and alternatively spliced isoforms of the same genes. The alternative splicing is a product of either intron retention or exon skipping during the splicing event of the initially transcribed full gene transcript [28,29]. This is a conserved process in higher organisms and plants [30]. Thus, the products that are formed differ from each other by having either additional or less amino acid stretches in certain regions of the protein, and therefore, may vary in activity, binding or localization. In this review, we focus on the role of distinct MAPKK and MAPK gene products at the protein level, including their alternative spliced forms, in extending signaling specificity and determining the proper cell fate in response to distinct stimulations.

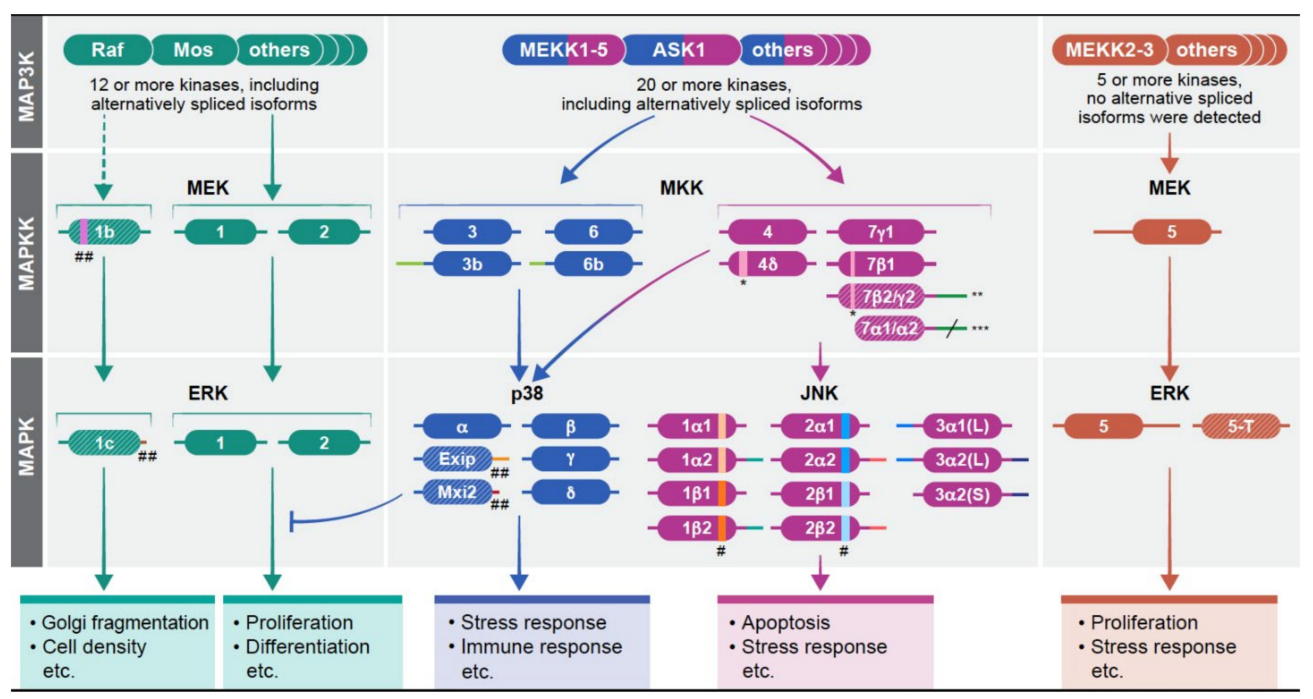

Figure 1. Signaling specificity and multiple isoforms of the MAPK signaling pathways. The MAPKs operate within signaling cascades composed of three to five layers (tiers) of protein kinases. The signals from the cascades are transmitted via sequential phosphorylation and activation of the components in each layer. The four cascades, which have been identified are shown: the human ERK1/2 cascade with MEK1/2/1b and ERK1/1c/2 at the MAPKK and MAPK layers. The p38MAPK cascade with MKK3/3b/6/6b, and p38 $\alpha /$ Exip/Mxi2/p38 $\beta / \mathrm{p} 38 \gamma / \mathrm{p} 388$; the JNK cascade with MKK $4 / 4 \delta / 7 \gamma 1 / \gamma 2 / \beta 1 / \beta 2 / \alpha 1 / \alpha 2$ and JNK1 $\alpha 1 / 1 \alpha 2 / 1 \beta 1 / 1 \beta 2 / 2 \alpha 1 / 2 \alpha 2 / 2 \beta 1 / 2 \beta 2 / 3 \alpha 1(\mathrm{~L}) / 3 \alpha 2(\mathrm{~L}) / 3 \alpha 2(\mathrm{~S}) ;$ and the ERK5 cascade with MEK5, and ERK5/5-T. It should be noted that the isoforms presented are those whose expression has been confirmed. Other alternatively spliced transcripts whose protein expression is not confirmed or may exist in other organisms are not presented here as well. The main proteins in each layer of each cascade (except for JNK) appear on top. As for JNK, it seems that all components may be substantially expressed, at least in some cells. Each of the kinases is composed of a kinase domain (central region) as well as $N$ and $C$ terminus represented by a line on the left ( $N$ terminus) and right (C terminus) of all kinase domains. The patterns in some of the proteins (e.g., MEK1b) represent low expression levels (less than $10 \%$ of the main gene product). Different colors and length in the $\mathrm{N}$ or $\mathrm{C}$ terminus represent distinct sequences and number of AA compared to the main isoform (e.g., ERK1c). In order to make changes more visible, the scale is not always accurate. ${ }^{*}$ insertion, ${ }^{* *} \beta 2$ without insertion, $\gamma 2$ with insertion, ${ }^{* * *} \alpha 1 / \alpha 2$ have different length $C$ termini, \# alternative exon 6 between the $\alpha$ and $\beta$ isoforms that result in a change of $5-7$ amino acids in this region. \#\# deletion. More information on the structure appears in Table 1. 


\section{Multiple Isoforms Extend Signaling Specificity of the MAPK Cascades}

One important way to extend the functions of the MAPK signaling cascades is through the existence of various components with distinct functions or regulations within each tier of the cascades. This is mostly apparent in the MAP3K tier of the four cascades, in which 2-20 distinct protein kinases may transmit distinct signals in response to varying stimulations. Unlike the considerable number of components in the upper tiers, the number of components in the MAPKK and MAPK tiers is more limited, encoded by one to four genes that in some cases may have several protein products generated by alternative splicing ([31], Figure 1, Table 1). For example, in the case of the ERK1, p38 $\alpha$ and ERK5, each gene has one main product and additional, lowly expressed, alternatively spliced isoforms. JNK1-3 are somewhat different, as each gene has several alternatively spliced protein products with substantial expression, which varies between cell lines. Overall, it is thought that the main MAPKKs and MAPKs components in each cascade, which are very similar to each other, funnel the signals towards their downstream targets without allowing much fluctuation. Nevertheless, in some cases, even minor sequence differences between these main components are sufficient to cause different activities (e.g., MEK1/2 that differ in their Pro-rich domain, as well as the $\mathrm{N}$ and $C$ termini [32]). Moreover, their specificity and functionality are extended by the minor alternative spliced isoforms, and the expression levels of the main components.

Table 1. Characteristics of the alternative spliced isoforms of the components of the MAPKKs and MAPKs of all four MAPK cascades. The alternatively spliced isoforms presented are only from proteins whose expression has been confirmed, although more lowly expressed forms whose transcripts have been identified may exist. The structural and functional properties of the lowly expressed alternatively spliced isoforms of the ERK1/2, p38, and ERK5 cascades are presented as compared to the main isoforms. These main isoforms are not presented here as their properties are very well covered in many other reviews. As for the components of the MAPKK tier of the JNK and p38 cascade, the alternatively spliced isoforms are presented as compared to the main isoforms MKK3, MKK6, MKK4 and MKK7 1 (not presented), whose expression is usually higher than the others, although the latter might be substantially expressed in some cells. Due to similar expression level of several JNKs, there is no "main" isoform and the comparison of the spliced isoforms is to the other components in the tier.

\begin{tabular}{|c|c|c|c|c|c|c|}
\hline & $\begin{array}{l}\text { Alternative } \\
\text { Spliced Forms }\end{array}$ & Product of: & Sequence Changes & MW & Functional Changes & Ref. \\
\hline \multirow[t]{6}{*}{ MAPKKs } & MEK1b & $\begin{array}{l}\text { MAP2K1 } \\
(\mathrm{MEK} 1)\end{array}$ & $\begin{array}{l}\text { Deletion of } 26 \text { AA in } \\
\text { subdomain } 5 \text { of MEK1. }\end{array}$ & $43.5 \mathrm{kDa}$ & $\begin{array}{l}\text { Reduced activity, change in } \\
\text { substrate specificity. }\end{array}$ & {$[33,34]$} \\
\hline & $\mathrm{MKK} 3 \mathrm{~b}$ & $\begin{array}{l}\text { MAP2K3 } \\
(\mathrm{MKK} 3)\end{array}$ & $\begin{array}{l}\text { Additional } 29 \text { amino acids } \\
\text { N-terminal to MKK3. }\end{array}$ & $40 \mathrm{kDa}$ & $\begin{array}{c}\text { Slightly Elevates substrates' } \\
\text { phosphorylation. }\end{array}$ & {$[35,36]$} \\
\hline & $\mathrm{MKK} 6 \mathrm{~b}$ & $\begin{array}{l}\text { MAP2K6 } \\
(\mathrm{MKK} 6)\end{array}$ & $\begin{array}{c}\text { Additional } 56 \text { amino acids } \mathrm{N} \\
\text { terminal to MKK6. }\end{array}$ & $38.5 \mathrm{kDa}$ & Affect substrate specificity. & {$[37,38]$} \\
\hline & $\mathrm{MKK} 7 \propto 1$ & $\begin{array}{l}\text { MAP2K7 } \\
(\mathrm{MKK} 7)\end{array}$ & $\begin{array}{c}\text { Deletion of the } \mathrm{N} \text { terminal } 89 \\
\text { AA of MKK7 } \gamma 1 .\end{array}$ & $40 \mathrm{kDa}$ & $\begin{array}{l}\text { Reduced activity due to lack } \\
\text { of JNK binding domain. }\end{array}$ & [39] \\
\hline & $\mathrm{MKK} 7 \alpha 2$ & $\begin{array}{l}\text { MAP2K7 } \\
(\mathrm{MKK} 7)\end{array}$ & $\begin{array}{l}\text { Deletion of the } \mathrm{N} \text { terminal } 89 \\
\mathrm{AA},+ \text { additional 33AA in the } \\
\mathrm{C} \text { terminus, compared } \\
\text { to MKK7 } \gamma 1 .\end{array}$ & $43.5 \mathrm{kDa}$ & $\begin{array}{l}\text { Reduced activity due to lack } \\
\text { of JNK binding }\end{array}$ & [39] \\
\hline & MKK7 $\beta 1$ & $\begin{array}{l}\text { MAP2K7 } \\
(\mathrm{MKK} 7)\end{array}$ & $\begin{array}{l}\text { Deletion of } 16 \text { amino within } \\
\text { the } N \text { terminus as compared } \\
\text { to MKK } 7 \gamma 1 \text {. }\end{array}$ & $50 \mathrm{kDa}$ & $\begin{array}{c}\text { Distinct subcelluar } \\
\text { localization, and lower } \\
\text { binding to JNK due to lack of } \\
\text { D domain. Distinct effect in } \\
\text { cancers compared to MKK7 } \gamma 1\end{array}$ & [39-42] \\
\hline
\end{tabular}


Table 1. Cont.

\begin{tabular}{|c|c|c|c|c|c|c|}
\hline & $\begin{array}{l}\text { Alternative } \\
\text { Spliced Forms }\end{array}$ & Product of: & Sequence Changes & MW & Functional Changes & Ref. \\
\hline & MKK7 $\beta 2$ & $\begin{array}{l}\text { MAP2K7 } \\
(\mathrm{MKK} 7)\end{array}$ & $\begin{array}{l}\text { Deletion of } 16 \text { amino within } \\
\text { the } N \text { terminus }+ \text { addition of } \\
33 \text { AA to the } C \text { terminus } \\
\text { compared to MKK } 7 \gamma 1 \text {. }\end{array}$ & $53.5 \mathrm{kDa}$ & $\begin{array}{l}\text { Distinct subcelluar } \\
\text { localization, a lower binding } \\
\text { to JNK and distinct effect in } \\
\text { cancers compared to MKK } 7 \gamma 1\end{array}$ & [39-42] \\
\hline & MKK7 $\gamma 2$ & $\begin{array}{l}\text { MAP2K7 } \\
(\mathrm{MKK} 7)\end{array}$ & $\begin{array}{c}\text { Addition of } 33 \text { AA to the } C \\
\text { terminus, as compared } \\
\text { to MKK7 } \gamma 1 .\end{array}$ & $53.5 \mathrm{kDa}$ & No known differences & [39] \\
\hline \multirow[t]{15}{*}{ МAPK } & ERK1c & $\begin{array}{l}\text { MAPK1 } \\
(\text { ERK1) }\end{array}$ & $\begin{array}{c}\text { Change of the } C \text { terminal } 40 \\
\text { AA with } 18 \text { other AA } \\
\text { compared to ERK } 1 .\end{array}$ & $41.5 \mathrm{kDa}$ & $\begin{array}{l}\text { Reduced activity and change } \\
\text { of substrate specificity as } \\
\text { compared with ERK1. }\end{array}$ & {$[33,43]$} \\
\hline & Exip & $\begin{array}{l}\text { MAPK14 } \\
(\mathrm{p} 38 \alpha)\end{array}$ & $\begin{array}{c}\text { Change of the } \mathrm{C} \text { terminal } 106 \\
\text { AA with } 53 \text { other AA } \\
\text { compared to p } 38 \alpha .\end{array}$ & $35.5 \mathrm{kDa}$ & $\begin{array}{l}\text { Reduced activity. Change in } \\
\text { subcellular localization and } \\
\text { protein interaction, as } \\
\text { compared to p } 38 \alpha\end{array}$ & {$[44,45]$} \\
\hline & Mxi2 & $\begin{array}{l}\text { MAPK14 } \\
(\mathrm{p} 38 \alpha)\end{array}$ & $\begin{array}{l}\text { Change of the } C \text { terminal } 81 \\
\text { AA with } 17 \text { other AA } \\
\text { compared to p } 38 \alpha .\end{array}$ & $34 \mathrm{kDa}$ & $\begin{array}{l}\text { Reduced activity, change in } \\
\text { substrate specificity, distinct } \\
\text { protein interaction, and } \\
\text { distinct regulation as } \\
\text { compared to p38 } \alpha \text {. }\end{array}$ & [46-48] \\
\hline & $\mathrm{JNK} 1 \alpha 1$ & $\begin{array}{l}\text { MAPK8 } \\
(\mathrm{JNK} 1)\end{array}$ & $\begin{array}{l}\text { Alternative exon } 6 \mathrm{a} \text {, Short } \\
\mathrm{C} \text { terminus }\end{array}$ & $46 \mathrm{kDa}$ & $\begin{array}{l}\text { Alternative substrate binding } \\
\text { compared to } \beta 1 \text { and } \beta 2 \text {. }\end{array}$ & {$[49,50]$} \\
\hline & $\mathrm{JNK} 1 \alpha 2$ & $\begin{array}{l}\text { MAPK8 } \\
(\mathrm{JNK} 1)\end{array}$ & $\begin{array}{c}\text { Alternative exon } 6 \mathrm{a} \text {, long } N \\
\text { terminus ( } 43 \mathrm{AA})\end{array}$ & $54 \mathrm{kDa}$ & $\begin{array}{l}\text { Alternative substrate binding } \\
\text { compared to } \beta 1 \text { and } \beta 2 \text {. }\end{array}$ & {$[49,50]$} \\
\hline & JNK1 $1 \beta 1$ & $\begin{array}{l}\text { MAPK8 } \\
(\mathrm{JNK} 1)\end{array}$ & $\begin{array}{l}\text { Alternative exon } 6 \mathrm{~b} \text {, short } \\
\qquad \mathrm{C} \text { terminus }\end{array}$ & $46 \mathrm{kDa}$ & $\begin{array}{l}\text { Changes in expression level } \\
\text { from } \alpha 1 \text { and } \alpha 2 \text {. }\end{array}$ & {$[49,50]$} \\
\hline & JNK1 $\beta 2$ & $\begin{array}{l}\text { MAPK8 } \\
(\mathrm{JNK} 1)\end{array}$ & $\begin{array}{c}\text { Alternative exon } 6 \mathrm{~b} \text {, long } N \\
\text { terminus ( } 43 \mathrm{AA})\end{array}$ & $54 \mathrm{kDa}$ & $\begin{array}{l}\text { Changes in expression level } \\
\text { from } \alpha 1 \text { and } \alpha 2 \text {. }\end{array}$ & {$[49,50]$} \\
\hline & $\mathrm{JNK} 2 \alpha 1$ & $\begin{array}{l}\text { MAPK9 } \\
(\text { JNK2) }\end{array}$ & $\begin{array}{l}\text { Alternative exon } 6 \mathrm{~b} \text {, short } \\
\qquad \text { terminus }\end{array}$ & $46 \mathrm{kDa}$ & $\begin{array}{l}\text { Alternative substrate binding } \\
\text { compared to } \beta 1 \text { and } \beta 2 \text {. }\end{array}$ & {$[49,50]$} \\
\hline & $\mathrm{JNK} 2 \alpha 2$ & $\begin{array}{l}\text { MAPK9 } \\
(\mathrm{JNK} 2)\end{array}$ & $\begin{array}{c}\text { Alternative exon } 6 \mathrm{~b} \text {, long } C \\
\text { terminus ( } 42 \mathrm{AA})\end{array}$ & $54 \mathrm{kDa}$ & $\begin{array}{l}\text { Alternative substrate binding } \\
\text { compared to } \beta 1 \text { and } \beta 2 \text {. }\end{array}$ & {$[49,50]$} \\
\hline & $\mathrm{JNK} 2 \beta 1$ & $\begin{array}{l}\text { MAPK9 } \\
(\text { JNK2) }\end{array}$ & $\begin{array}{l}\text { Alternative exon } 6 a \text {, short } \\
\qquad \text { terminus }\end{array}$ & $46 \mathrm{kDa}$ & $\begin{array}{l}\text { Alternative substrate binding } \\
\text { compared to } \alpha 1 \text { and } \alpha 2 \text {. }\end{array}$ & {$[49,50]$} \\
\hline & JNK $2 \beta 2$ & $\begin{array}{l}\text { MAPK9 } \\
(\mathrm{JNK} 2)\end{array}$ & $\begin{array}{c}\text { Alternative exon } 6 \mathrm{a} \text {, long } \mathrm{C} \\
\text { terminus }(42 \mathrm{AA}\end{array}$ & $54 \mathrm{kDa}$ & $\begin{array}{l}\text { Alternative substrate binding } \\
\text { compared to } \alpha 1 \text { and } \alpha 2 \text {. }\end{array}$ & {$[49,50]$} \\
\hline & $\mathrm{JNK} 3 \alpha 1(\mathrm{~L})$ & $\begin{array}{l}\text { MAPK10 } \\
\text { (JNK3) }\end{array}$ & $\begin{array}{l}\text { Long } N \text { terminus (38 AA) } \\
\text { short } C \text { terminus. }\end{array}$ & $50.5 \mathrm{kDa}$ & $\begin{array}{l}\text { Probable changes in } \\
\text { protein interaction. }\end{array}$ & [49-51] \\
\hline & JNK3 $22(\mathrm{~L})$ & $\begin{array}{l}\text { MAPK10 } \\
\text { (JNK3) }\end{array}$ & $\begin{array}{l}\text { Long } N \text { terminus ( } 38 \mathrm{AA} \text { ) } \\
\text { Long } C \text { terminus ( } 42 \mathrm{AA}) \text {. }\end{array}$ & $58.5 \mathrm{kDa}$ & $\begin{array}{l}\text { Probable changes in } \\
\text { protein interaction. }\end{array}$ & [49-51] \\
\hline & $\mathrm{JNK} 3 \alpha 2(\mathrm{~S})$ & $\begin{array}{l}\text { MAPK10 } \\
\text { (JNK3) }\end{array}$ & $\begin{array}{l}\text { Short } N \text { and long } C \text { termini } \\
\text { (42 AA). }\end{array}$ & $54 \mathrm{kDa}$ & $\begin{array}{l}\text { Probable changes in } \\
\text { protein interaction. }\end{array}$ & [49-51] \\
\hline & ERK5-T & $\begin{array}{l}\text { MAPK7 } \\
(\text { ERK5) }\end{array}$ & $\begin{array}{c}\text { Change of the } C \text { terminal } 324 \\
\text { AA with } 41 \text { other AA. }\end{array}$ & $61 \mathrm{kDa}$ & $\begin{array}{c}\text { Distinct subcellular } \\
\text { localization and protein } \\
\text { binding compared to ERK5. }\end{array}$ & [52] \\
\hline
\end{tabular}

The signaling outcome of the different components in each tier of each cascade may also be regulated by their cognate expression levels. This point became apparent in the ERK components in knockout mice $[53,54]$. Whereas knockout of ERK1 has very little effect on mice survival [55], the knockout of ERK2 is embryonic lethal due to placental defects and defective mesoderm differentiation [56,57]. It was later shown that this is due to expression levels in the early stages of development $[58,59]$. Similar expression-related changes were shown for other MAPKKs and MAPKs (e.g., MEK1/2, or p38 $\alpha / \beta[53,54]$ ), but not in the JNK cascade, in which the small differential effects are mainly due to distinct activities and regulation of the components $[60,61]$. Importantly, in the ERK and p38 cascades, it is clear that the $\mathrm{KO}$ mice lack not only the main isoforms, but also the minor alternatively spliced 
ones. This, as well as the low expression levels and lack of sequence conservation among species initially raised questions about the function of the minor forms [62]. However, the accumulating data described below suggest that these forms do appear in many cell types and tissues, and may participate in unique signaling processes that are not essential for embryonic development [33]. It is possible that in knockout cells, the activity of these minute isoforms is compensated for by other components. Thus, despite the assumed linearity of the MAPKK-MAPK tiers, under some conditions they disseminate the signal to extend the signaling repertoire. Therefore, here we provide a detailed review of the redundant and unique roles of the MAPKK and MAPK in JNK, p38 and ERK cascades. We do not, however, cover the ERK5 cascade due to its limited number of components [63-65].

\section{Redundant and Unique Roles of MAPKKs and MAPKs of the JNK Cascade}

The MAPKKs of the JNK cascade are MKK4 (that also phosphorylates p38s), and MKK7, which have two [66] and six [39] spliced isoforms, respectively. They have one (MKK4) or two (MKK7) main isoforms, while the other spliced isoforms are less abundant, and the evidence for their protein expression is still limited. The main isoforms are similar to each other in their sequence as well as in their mode of activation by MAP3Ks. However, despite their sequence similarity $(\sim 75 \%)$, the main isoforms of MKK4 and MKK7 have distinct features that result in different activities. In particular, while MKK7 is specific to JNKs, MKK4 can also phosphorylate p38 and induce its full activation [67]. Moreover, the rate of phosphorylation of the Tyr and Thr residues within the JNKs is significantly different. MKK4 favors phosphorylating the Tyr within the TPY domain, while MKK7 preferentially phosphorylates the Thr residue [68]. This suggests that the full activation of JNKs in vivo may sometimes require a combined phosphorylation by the two MKKs. Interestingly, the knockout of each of the two genes is embryonic lethal, supporting the suggestion that they have unique functions [69-71]. Aside from the main isoforms, alternatively spliced isoforms may provide additional regulation. Thus, MKK4 [66] is substantially (although less than the main MKK4 isoform) expressed in most mammalian tissues and induces cell proliferation rather than preventing it as the main isoform. As mentioned above, MKK7 has six isoforms, composed of three spliced isoforms in the $N$ terminus $(\alpha-\gamma)$ and two in the $C$ terminus, named as 1 or 2 [39]. In different cells, there might be different spliced isoforms of MKK7 that serve as a main JNK activating kinase ( $>85 \%$ of the gene products), which is typically either MKK7 $\gamma 1$ [40,72] or MKK7 $\beta 1$ [42]). The expression of MKK7 $\beta 2$ and $\gamma 2$ is usually somewhat lower, while $M K K 7 \alpha 1 / 2$ are lowly expressed. Besides their differences in expression, MKK7 isoforms also differ in their activity (MKK7 $\alpha 1 / 2$ are less active), and in their ability to bind scaffold proteins (e.g., Filamin [73] or JIP1 [74]). Finally, during T cell activation, MKK7 splicing is mediated by CELF2, which favors the MKK7 $\gamma 1$ isoform. This process is positively regulated by JNK, and thus consists a positive feedback loop upon stimulation [75].

The MAPK components in the JNK cascades, JNK1 and JNK2, are each transcribed into four confirmed transcripts, and JNK3 has three highly similar alternatively spliced isoforms $[49,50]$. The alternatively spliced isoforms of JNK1 and JNK2 result from either the inclusion of alternative sequences in intron 6 (either $\alpha$ or $\beta$ ), or different exons in the C-termini known as 1 or $2[49,76]$. The alternatively spliced isoforms of JNK3 have either elongated $N$ or $C$ termini ((JNK3 $\alpha 1(\mathrm{~L}), \mathrm{JNK} 3 \alpha 2(\mathrm{~L})$ or $(\mathrm{JNK} 3 \alpha 2(\mathrm{~S}))$, which give rise to different size proteins. Other alternative spliced isoforms of these genes are transcribed into RNA but have not been found in the protein level. Interestingly, only double-knockout mice of JNK1 and JNK2 are embryonic lethal due to severe brain malformation, while the knockout of each one alone, or together with JNK3, results in viable animals with limited metabolic, immunological, and other pathologies [77,78]. Moreover, each one of the JNK proteins has similar catalytic activity towards most substrates, such as Ser34 of p53 [79], indicating that JNK1, JNK2, and to some extent JNK3 are mostly functionally redundant. However, the relative protein expression of JNK1 and JNK2 isoforms varies between tissues and cells, though all are ubiquitously expressed, while JNK3 is expressed 
almost exclusively in the brain and testis. The variable expression contributes to the limited differences in the single knockout animals, which results mostly from distinct signaling specificity exerted by tissue-specific substrates and interactions [50,80,81]. Among other outcomes, JNK1 knockout mice demonstrate a dysregulated neuronal differentiation during development [82], while JNK3 knockout effects on the developing brain are more limited, showing mainly hippocampal neurogenesis malformations [83,84]. JNK2 does not seem to participate in these processes, but plays a major role in carcinogenesis [85]. In addition, there are some cases in which the actions of JNK1 and JNK2 are cooperative or even synergistic, such as the development of skin keratinocytes [86] or UV- and arsenite-induced apoptosis [87]. As for the alternatively spliced forms of JNK2, it was shown that JNK $2 \alpha 3$ has higher activity towards the transcription factor AP-1 than JNK2 $\beta 3$ [88]. Another study revealed that the short JNK proteins are less stable than the long isoforms due to the interaction of the latter with the scaffold protein JIP1 [89]. This stability modulation represents a new mechanism to regulate the JNK pathway. Thus, it is clear that the different JNK components can provide extended specificity to the cascade in response to various stimulations.

\section{Redundant and Unique Roles of MAPKKs and MAPKs of the p38 Cascade}

The MAPKKs of the p38 cascade are MKK3, MKK6, and occasionally also MKK4. Each of them has two alternatively spliced isoforms that are substantially expressed, but the expression level of the main isoforms (MKK3/MKK6), although varied between cells, are always higher than the expression of the other $(\mathrm{MKK} 3 \mathrm{~b} / 6 \mathrm{~b})[35,37]$. The human MKK3 and MKK6 are similar in their primary sequences $(\sim 80 \%)$, and in their ability to phosphorylate the TGY motifs of a given p38 protein [37]. However, each is activated by distinct stimuli [37], and preferentially (but not exclusively) phosphorylate distinct p38 isoforms [90-92]. In addition, it was shown that the balance between MKK3 and MKK6 mediates p38-associated resistance to cisplatin [93]. During development, MKK3/6 are mostly functionally redundant, as knockout of each of them individually does not affect viability, while simultaneous knockout of both is embryonic lethal due to problems in the hematopoietic system [94]. Interestingly, MKK3 and MKK6 have process, or cell typespecific, functions. For example in the differentiation of T cells, the individual knockouts yielded aberrant $\mathrm{T}$ cell maturation and function [95], but those differences are not sufficient to induce embryonic lethality. No particular differences in activity have been demonstrated for the distinct alternatively spliced isoforms, and although the main isoforms are the most active in most cases, MKK3b and $6 \mathrm{~b}$ may also serve as the main $\mathrm{p} 38 \alpha-\delta$ activators under some conditions $[38,96]$.

Four p38 MAPKs genes $(\alpha-\delta)$ have been identified in humans, p38 $\alpha$ has $\sim 80 \%$ identity to p38 $\beta$ (also known as p38 $\beta 2$ ), while p38 $\gamma$ has $\sim 80 \%$ identity to p38 , but the p38 $\alpha / \beta$ pair has just $60 \%$ identity to the $\mathrm{p} 38 \gamma / \delta$ pair $[14,97]$. The only spliced variants reported are of p38 $\alpha$ (Exip and Mxi2), which are both lowly expressed. Interestingly, all of the main gene-products are able to phosphorylate similar substrates and share similar regulation. However, in some cases they display distinct properties and differ in their substrate specificity. For example, it was shown that $\mathrm{p} 38 \alpha / \beta$ phosphorylate MK2 and MK3 better than $\mathrm{p} 38 \gamma / \delta$ [98], while the latter phosphorylate the tau protein better [99]. These changes are probably due to differences in their substrate binding. While p38 $\alpha$ is ubiquitously expressed, the expression of the other three isoforms varies or is even restricted to specific tissues. Knockout of p38 $\alpha$ is embryonic lethal due to placental defects [100], while p38 $\beta-\delta$ knockout mice are viable and fertile [101,102]. The different effects may be mediated by distinct expression of the isoforms or by a difference in substrate repertoire. The specificity of the p38 is also extended by the alternatively spliced proteins of p38 $\alpha$. The first confirmed alternatively spliced form of p38 $\alpha$ was named Exip (exon skip), whose $C$ terminus is modified, and it is considerably less abundant than the main p38 $\alpha$ isoform $[44,45]$. Exip is not phosphorylated on its activatory TGY motif due to lack of MAPKKs binding sites, but it can induce earlier apoptotic onset upon stress or by binding to a Toll receptor. The second 
lowly expressed spliced variant is Mxi2 (Max interactor), which affects the c-Myc transcriptional activity [46]. It has a unique 17 amino acids in subdomain XI, and lacks the whole C-terminus [47]. Mxi2 is usually poorly expressed, but it is found in relatively high amounts in mouse kidney where its expression level is reduced by ischemia [103]. It was also shown that Mxi2 interacts with ERK1/2, regulating their non-stimulated nuclear translocation and sustaining their nuclear phosphorylation $[48,104,105]$. Interestingly, it was recently shown that Mxi2 is highly expressed in prostate cancer, where it increases the aggressiveness of the disease, acting mainly by interacting with the Argonaut $2 /$ mir 1285 complex that further regulate p53 activity [106]. Moreover, osmotic stress induces p38-dependent alterative splicing by inducing p38 activation and phosphorylation of the spliceosome component SKIIP [107]. Phosphorylated SKIIP phosphorylation then modulates the alternative splicing of GADD $45 \alpha$, which is an upstream activator of the p38 pathway. These findings suggest that the phosphorylation of SKIIP by p38 forms a feedback loop that regulates various alternative splicing events.

\section{The MEK1b-ERK1c Axis}

The main proteins translated by the ERK1 and ERK2 genes are the 44 and $42 \mathrm{kDa}$ isoforms, respectively. These isoforms usually share similar characteristics, although some differences between them do exist under restricted conditions or in specific cell types [108-117]. Aside from these main isoforms, initial studies reported the existence of additional, slightly different transcripts called ERK1psi [118] and ERK2a [119]; however, these transcripts exist only on the RNA level and are not translated into a stable protein. On the other hand, the use of pan-ERK antibodies revealed an additional band of $46 \mathrm{kDa}$ in rat-derived cells. This band was not initially cloned and was tentatively labeled ERK4 [118]. Later on, the band was also found in mice, but not in humans, and was further studied by our group. This latter study was based on in-gel kinase assay of rat cells that aimed to identify elevated kinase activity in transformed cells. One phosphorylated band at $46 \mathrm{kDa}$ stood out as the most notable kinase activity, and was even increased after Ras transformation. This band was purified and cloned, giving rise to an alternatively spliced isoform of ERK1 with a 26 amino acid insertion (intron 7) inside the common docking motif (CD) of ERK1 of rat and mouse. The expression of this isoform was much lower than that of ERK1 and ERK2, consisting of 1-10\% of the total rodent ERK proteins. Further characterization confirmed the similarity of this protein to the band originally identified as ERK4, and therefore it was renamed ERK1b. Under many circumstances, ERK1b behaves similarly to ERK1/2, but in Ras-transformed Rat1 cells, the expression level of ERK1b is elevated, and it is phosphorylated in a different kinetic than the main isoforms. Additionally, ERK1b was shown to be the major isoform that transmits extracellular signals in transformed cells. The reason for the distinct regulation is the alteration in the CD domain, which results in distinct binding to scaffolds, substrates, activators and phosphatases.

The lack of $46 \mathrm{kDa}$ band in other organisms prompted a study that aimed to identify whether any alternative spliced isoform is generated in humans. Using PCR, Aebersold et al. demonstrated that inclusion of ERK1's intron 7 does occur in human as well, although the amount of expression may vary between cell types [43]. However, since the intron contains an in-frame stop codon in humans, the translation of this isoform resulted in a $42 \mathrm{kDa}$ protein. This splicing event alters the C-terminal, containing 18 unique AA sequence in the very $C$ terminus of the protein that is different than the CD domain of ERK1. Since the primate's alternatively spliced isoform was different from the rodent ERK1b, it was named ERK1c. This protein migrates to the same place as ERK2 on SDS-PAGE, and therefore cannot be detected by pan-ERK antibodies. However, the expression of this protein was confirmed using specific antibody to the unique ERK1c sequence, which detected low expression ( 10 of ERK1) in various human cells [43]. Unlike the diffused subcellular localization of ERK1/2, ERK1c was found localized all over the cytoplasm in some cells, while in G2/M cells, it was localized primarily in the Golgi. In depth study of this phenotype revealed that ERK1c regulates Golgi fragmentation, which was specifically prevented by 
expression of dominant-negative ERK1c. Moreover, the expression and activity of ERK1c is increased upon mitosis followed by its accumulation in the Golgi where it regulates mitotic Golgi fragmentation [120]. Indeed, small interfering RNA specific to ERK1c (with no effect on ERK1 or any other protein tested) significantly attenuated this process, whereas ERK1c overexpression facilitated it. These effects were also reflected in mitotic progression, indicating that ERK1c is involved in cell cycle regulation via modulation of Golgi fragmentation. The main isoforms of ERK1 and ERK2 are active in mitosis as well, but do not significantly replace ERK1c.

One question that was unsolved at this stage was the way in which ERK1c is activated. This question was raised due to the replacement of the residues just C-terminal to the CD that suggest a reduced interaction with the upstream activators MEK1 and MEK2. Using the three MEK constructs in a different study, Shaul et al. found that ERK1c is preferentially activated by MEK1b and not by MEK1 or MEK2 [33]. Interestingly, MEK1b was initially considered an inactive isoform, because it was unable to phosphorylate the main isoform of ERK1 and ERK2 [121]. Apparently, these results indicate that this alternatively spliced isoform has a unique specificity towards ERK1c. Additionally, Shaul et al. showed that MEK1b phosphorylation and activity are preferentially stimulated by mitotic inducers (e.g., nocodazole) rather than growth factors or stress mediators, to induce its specific activity toward ERK1c in mitosis (Figure 2). MEK1/2, on the other hand, preferentially target ERK1/2 and not ERK1c in response to mitogens, without affecting the Golgi [122]. Importantly, similarly to ERK1c, MEK1b expression and activity are elevated during mitosis, though this isoform is localized primarily in the Golgi throughout the cell cycle. These results indicate that the ERK cascade can be divided into two routes: the classic MEK1/2-ERK1/2 route that mediates most extracellular signals, and the splice-variants MEK1b-ERK1c route that specifically regulates mitotic Golgi fragmentation, and thus extends the specificity of the ERK cascade.

Since ERK1c is localized in the cytoplasm of cycling cells, Wortzel et al. studied the molecular machinery that regulates its translocation to the Golgi during mitosis. It was found that this translocation is mediated at the prophase and prometaphase, and requires CDK1-induced phosphorylation of Ser343 of ERK1c [123,124]. This phosphorylation then facilitates binding of phosphorylated ERK1c to a protein complex of PI4KIII $\beta$ and 14-3-3 $\gamma$. Interestingly, the stability of this complex is regulated by protein kinase D (PKD)-mediated phosphorylation of PI4KIII $\beta$. Thus, ERK1c joins a small group of other Golgi shuttling proteins at G2 to $\mathrm{M}$ phase transition that integrate Golgi-regulating processes such as fragmentation into one coherent pathway. To better understand the function of ERK1c, Wortzel et al. recently studied the ERK1c-specific substrates that regulate Golgi fragmentation [125]. By screening several putative phosphorylated Golgi proteins, HOOK3 was identified as a mediator of ERK1c-induced Golgi fragmentation. ERK1c phosphorylates HOOK3 on Ser238, which is a prerequisite for an additional phosphorylation on Ser707 by AuroraA kinase. In cycling cells, HOOK3 interacts with microtubules (MTs) and links them to the Golgi to induce the stabilization of the organelle. During mitosis, the double phosphorylation of HOOK3 by ERK1c and AuroraA allows the detachment of HOOK3 from the MTs, and its interaction with the Golgi architectural protein GM130. This switch in HOOK3's interactions reduces the Golgi stability, which permits Golgi fragmentation. Thus, ERK1c supports the Golgi fragmentation process by shuttling into the Golgi towards mitosis, where it is activated by the resident MEK1b. The active ERK1c then phosphorylates several substrates including HOOK 3 to set the stage for the fragmentation. 

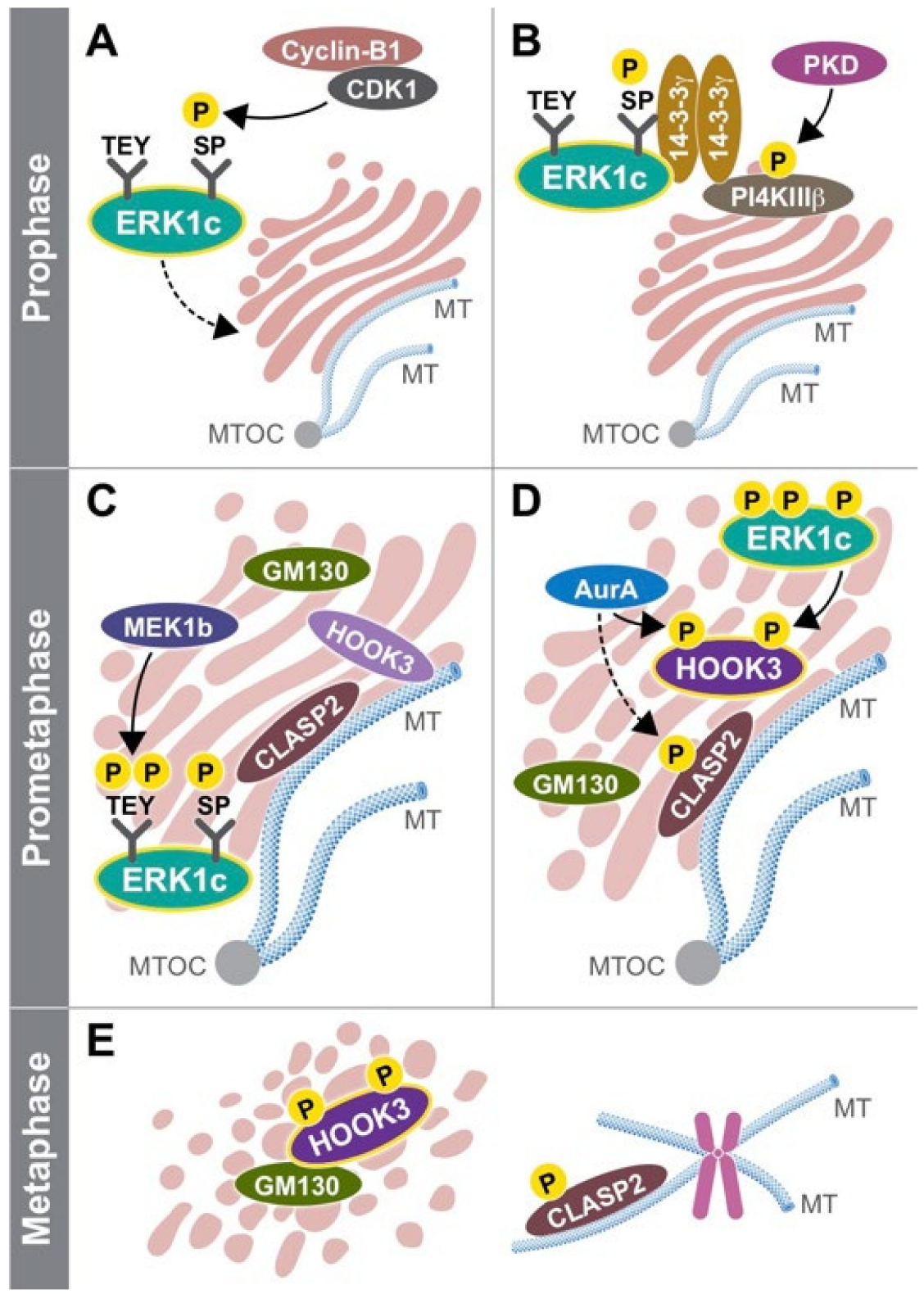

Figure 2. Schematic presentation of ERK1c function in the Golgi. An illustration demonstrating the unique role of ERK1c isoform in the Golgi fragmentation process at different stages of the cell cycle. Prophase: (A) CDK1 becomes active, and phosphorylates ERK1c on Ser343 in its unique C-terminus. (B) Phosphorylated ERK1c interacts with a shuttling complex of PI4KIII $\beta$ and 14-3-3 $\gamma$, which mediates its Golgi translocation. Prometaphase: (C) In the Golgi, ERK1c is phosphorylated by MEK1b, becomes fully active and induces mitotic Golgi fragmentation. The Golgi is organized in stacks, while GM130 is found in between these stacks. The microtubules (MTs) are polymerized from the microtubules originating center (MTOC) and stabilize the Golgi structure. Both HOOK3 and CLASP2 interact together with the MTs and Golgi. (D) Once entering mitosis, HOOK3 is phosphorylated by both ERK1c and AurA, while CLASP2 might be phosphorylated by AurA. At this time the Golgi stacks starts to break into ribbons. Metaphase: (E) The phosphorylation of HOOK3 and CLASP2 allow the complete fragmentation of the Golgi into a haze. At this time, phosphorylated CLASP2 maintains its interaction with the MTs that originate from the centromeres, while phosphorylated HOOK3 interacts with GM130. 


\section{Conclusions}

The MAPK cascades are central pathways that disseminate the signals of essentially all extracellular stimuli. Although all these cascades use a similar mechanism to transmit the signals, each cascade leads to a variety of distinct downstream activities and cellular fate. These differences raise the question of signaling specificity, and this review demonstrates that despite the similarity of the components of each tier in each cascade, they have substantial variability that extends the signaling repertoire, and allows each stimulation to secure the proper cell fate.

Many studies have suggested that the components in each tier of each MAPK cascade are very similar to each other and may have redundant effects. The evidence presented in this review clearly shows that despite this similarity, the different components present distinct expression and activities that make the cascades less linear than expected. An important example shown here is the MEK1b-ERK1c axis, which presents a separate signaling route with distinct activity compared to the main ERK isoforms. More studies on the activities of the distinct isoforms of each MAPK cascade component, including the alternatively spliced isoforms are required to expand our understanding of the signaling specificity of the MAPK cascades. As for the MEK1b-ERK1c axis, it seems to specifically regulate cell cycle progression, and therefore, may be used as a clinical target for cancer and other diseases. Similarly, the involvement of Mxi2 in regulating prostate cancer should make it a specific target for this disease. Therefore, these two isoforms should be investigated in detail, mainly by isolating additional specific substrates of ERK1c or Mxi2 to determine their mechanism of action in health and disease. Thus, alternatively spliced isoforms extend signaling specificity, and are essential for decisions regarding the proper cell fate. Further studies are required to understand their exact roles and how they can be utilized as clinical targets.

Author Contributions: G.M.-R., I.W. and R.S. wrote the review. All authors have read and agreed to the published version of the manuscript.

Funding: The writing of this review was supported by a grant from Madame Olga Klein-Astrachan. RS is an incumbent of the Yale Lewine and Ella Miller Lewine professorial chair for cancer research.

Data Availability Statement: All data appear in the review.

Conflicts of Interest: The authors declare no conflict of interest.

\section{References}

1. Keshet, Y.; Seger, R. The MAP kinase signaling cascades: A system of hundreds of components regulates a diverse array of physiological functions. Methods Mol. Biol. 2010, 661, 3-38. [CrossRef] [PubMed]

2. Flores, K.; Yadav, S.S.; Katz, A.A.; Seger, R. The Nuclear Translocation of Mitogen-Activated Protein Kinases: Molecular Mechanisms and Use as Novel Therapeutic Target. Neuroendocrinology 2019, 108, 121-131. [CrossRef] [PubMed]

3. Plotnikov, A.; Zehorai, E.; Procaccia, S.; Seger, R. The MAPK cascades: Signaling components, nuclear roles and mechanisms of nuclear translocation. Biochim. Biophys. Acta 2011, 1813, 1619-1633. [CrossRef] [PubMed]

4. Lee, S.; Rauch, J.; Kolch, W. Targeting MAPK Signaling in Cancer: Mechanisms of Drug Resistance and Sensitivity. Int. J. Mol. Sci. 2020, 21, 1102. [CrossRef]

5. Tajan, M.; Paccoud, R.; Branka, S.; Edouard, T.; Yart, A. The Rasopathy family: Consequences of germline activation of the RAS/MAPK pathway. Endocr. Rev. 2018, 39, 676-700. [CrossRef] [PubMed]

6. Collins, L.M.; Downer, E.J.; Toulouse, A.; Nolan, Y.M. Mitogen-Activated Protein Kinase Phosphatase (MKP)-1 in Nervous System Development and Disease. Mol. Neurobiol. 2015, 51, 1158-1167. [CrossRef] [PubMed]

7. Maik-Rachline, G.; Hacohen-Lev-Ran, A.; Seger, R. Nuclear ERK: Mechanism of Translocation, Substrates, and Role in Cancer. Int J. Mol. Sci. 2019, 20, 1194. [CrossRef]

8. Lu, N.; Malemud, C.J. Extracellular Signal-Regulated Kinase: A Regulator of Cell Growth, Inflammation, Chondrocyte and Bone Cell Receptor-Mediated Gene Expression. Int. J. Mol. Sci. 2019, 20, 3792. [CrossRef]

9. Klomp, J.E.; Klomp, J.A.; Der, C.J. The ERK mitogen-activated protein kinase signaling network: The final frontier in RAS signal transduction. Biochem. Soc. Trans. 2021, 49, 253-267. [CrossRef] [PubMed]

10. Lavoie, H.; Gagnon, J.; Therrien, M. ERK signalling: A master regulator of cell behaviour, life and fate. Nat. Rev. Mol. Cell Biol. 2020, 21, 607-632. [CrossRef]

11. Hotamisligil, G.S.; Davis, R.J. Cell Signaling and Stress Responses. Cold Spring Harb. Perspect. Biol. 2016, 8, a006072. [CrossRef] 
12. Ha, J.; Kang, E.; Seo, J.; Cho, S. Phosphorylation Dynamics of JNK Signaling: Effects of Dual-Specificity Phosphatases (DUSPs) on the JNK Pathway. Int. J. Mol. Sci. 2019, 20, 6157. [CrossRef] [PubMed]

13. Dhanasekaran, D.N.; Reddy, E.P. JNK-signaling: A multiplexing hub in programmed cell death. Genes Cancer 2017, 8, 682-694. [CrossRef]

14. Canovas, B.; Nebreda, A.R. Diversity and versatility of p38 kinase signalling in health and disease. Nat. Rev. Mol. Cell Biol. 2021, 27, 1-21. [CrossRef] [PubMed]

15. Maik-Rachline, G.; Lifshits, L.; Seger, R. Nuclear P38: Roles in Physiological and Pathological Processes and Regulation of Nuclear Translocation. Int. J. Mol. Sci. 2020, 21, 6102. [CrossRef] [PubMed]

16. Han, J.; Wu, J.; Silke, J. An overview of mammalian p38 mitogen-activated protein kinases, central regulators of cell stress and receptor signaling. F1000Res 2020, 9. [CrossRef]

17. Hoang, V.T.; Yan, T.J.; Cavanaugh, J.E.; Flaherty, P.T.; Beckman, B.S.; Burow, M.E. Oncogenic signaling of MEK5-ERK5. Cancer Lett. 2017, 392, 51-59. [CrossRef] [PubMed]

18. Tubita, A.; Lombardi, Z.; Tusa, I.; Dello Sbarba, P.; Rovida, E. Beyond Kinase Activity: ERK5 Nucleo-Cytoplasmic Shuttling as a Novel Target for Anticancer Therapy. Int. J. Mol. Sci. 2020, 21, 938. [CrossRef] [PubMed]

19. Coulombe, P.; Meloche, S. Atypical mitogen-activated protein kinases: Structure, regulation and functions. Biochim. Biophys. Acta 2007, 1773, 1376-1387. [CrossRef]

20. Shaul, Y.D.; Seger, R. The MEK/ERK cascade: From signaling specificity to diverse functions. Biochim. Biophys. Acta 2007, 1773, 1213-1226. [CrossRef]

21. Marshall, C.J. Specificity of receptor tyrosine kinase signaling: Transient versus sustained extracellular signal-regulated kinase activation. Cell 1995, 80, 179-185. [CrossRef]

22. Kolch, W. Coordinating ERK/MAPK signalling through scaffolds and inhibitors. Nat. Rev. Mol. Cell Biol. 2005, 6, 827-837. [CrossRef] [PubMed]

23. Nguyen, L.K.; Kolch, W.; Kholodenko, B.N. When ubiquitination meets phosphorylation: A systems biology perspective of EGFR/MAPK signalling. Cell Commun Signal 2013, 11, 52. [CrossRef]

24. Kim, Y.; Andreu, M.J.; Lim, B.; Chung, K.; Terayama, M.; Jimenez, G.; Berg, C.A.; Lu, H.; Shvartsman, S.Y. Gene regulation by MAPK substrate competition. Dev. Cell 2011, 20, 880-887. [CrossRef] [PubMed]

25. Wainstein, E.; Seger, R. The dynamic subcellular localization of ERK: Mechanisms of translocation and role in various organelles. Curr. Opin. Cell Biol. 2016, 39, 15-20. [CrossRef] [PubMed]

26. Chuderland, D.; Konson, A.; Seger, R. Identification and characterization of a general nuclear translocation signal in signaling proteins. Mol. Cell 2008, 31, 850-861. [CrossRef]

27. Plotnikov, A.; Flores, K.; Maik-Rachline, G.; Zehorai, E.; Kapri-Pardes, E.; Berti, D.A.; Hanoch, T.; Besser, M.J.; Seger, R. The nuclear translocation of ERK1/2 as an anticancer target. Nat. Commun. 2015, 6, 6685. [CrossRef]

28. Wahl, M.C.; Will, C.L.; Luhrmann, R. The spliceosome: Design principles of a dynamic RNP machine. Cell 2009, 136, 701-718. [CrossRef] [PubMed]

29. Kornblihtt, A.R.; Schor, I.E.; Allo, M.; Dujardin, G.; Petrillo, E.; Munoz, M.J. Alternative splicing: A pivotal step between eukaryotic transcription and translation. Nat. Rev. Mol. Cell Biol. 2013, 14, 153-165. [CrossRef]

30. McGuire, A.M.; Pearson, M.D.; Neafsey, D.E.; Galagan, J.E. Cross-kingdom patterns of alternative splicing and splice recognition. Genome Biol. 2008, 9, R50. [CrossRef] [PubMed]

31. Siegfried, Z.; Bonomi, S.; Ghigna, C.; Karni, R. Regulation of the Ras-MAPK and PI3K-mTOR Signalling Pathways by Alternative Splicing in Cancer. Int. J. Cell Biol. 2013, 2013, 568931. [CrossRef] [PubMed]

32. Catalanotti, F.; Reyes, G.; Jesenberger, V.; Galabova-Kovacs, G.; de Matos Simoes, R.; Carugo, O.; Baccarini, M. A Mek1-Mek2 heterodimer determines the strength and duration of the Erk signal. Nat. Struct. Mol. Biol. 2009, 16, 294-303. [CrossRef] [PubMed]

33. Shaul, Y.D.; Gibor, G.; Plotnikov, A.; Seger, R. Specific phosphorylation and activation of ERK1c by MEK1b: A unique route in the ERK cascade. Genes Dev. 2009, 23, 1779-1790.

34. Seger, R.; Seger, D.; Lozeman, F.J.; Ahn, N.G.; Graves, L.M.; Campbell, J.S.; Ericsson, L.; Harrylock, M.; Jensen, A.M.; Krebs, E.G. Human T-cell Map kinase kinases are related to yeast signal transduction kinases. J. Biol. Chem. 1992, 267, 25628-25631. [CrossRef]

35. Moriguchi, T.; Toyoshima, F.; Gotoh, Y.; Iwamatsu, A.; Irie, K.; Mori, E.; Kuroyanagi, N.; Hagiwara, M.; Matsumoto, K.; Nishida, E. Purification and identification of a major activator for p38 from osmotically shocked cells. Activation of mitogen-activated protein kinase kinase 6 by osmotic shock, tumor necrosis factor-alpha, and H2O2. J. Biol. Chem. 1996, 271, 26981-26988. [CrossRef] [PubMed]

36. Han, J.; Wang, X.; Jiang, Y.; Ulevitch, R.J.; Lin, S. Identification and characterization of a predominant isoform of human MKK3. FEBS Lett. 1997, 403, 19-22. [CrossRef]

37. Han, J.; Lee, J.D.; Jiang, Y.; Li, Z.; Feng, L.; Ulevitch, R.J. Characterization of the structure and function of a novel MAP kinase kinase (MKK6). J. Biol. Chem. 1996, 271, 2886-2891. [CrossRef] [PubMed]

38. Huang, S.; Jiang, Y.; Li, Z.; Nishida, E.; Mathias, P.; Lin, S.; Ulevitch, R.J.; Nemerow, G.R.; Han, J. Apoptosis signaling pathway in T cells is composed of ICE/Ced-3 family proteases and MAP kinase kinase 6b. Immunity 1997, 6, 739-749. [CrossRef]

39. Tournier, C.; Whitmarsh, A.J.; Cavanagh, J.; Barrett, T.; Davis, R.J. The MKK7 gene encodes a group of c-Jun NH2-terminal kinase kinases. Mol. Cell. Biol. 1999, 19, 1569-1581. [CrossRef] 
40. Gibson, E.S.; Woolfrey, K.M.; Li, H.; Hogan, P.G.; Nemenoff, R.A.; Heasley, L.E.; Dell'Acqua, M.L. Subcellular Localization and Activity of the Mitogen-Activated Protein Kinase Kinase 7 (MKK7) gamma Isoform are Regulated through Binding to the Phosphatase Calcineurin. Mol. Pharmacol. 2019, 95, 20-32. [CrossRef]

41. Ho, D.T.; Bardwell, A.J.; Grewal, S.; Iverson, C.; Bardwell, L. Interacting JNK-docking sites in MKK7 promote binding and activation of JNK mitogen-activated protein kinases. J. Biol. Chem. 2006, 281, 13169-13179. [CrossRef] [PubMed]

42. Ray, D.; Yun, Y.C.; Idris, M.; Cheng, S.; Boot, A.; Iain, T.B.H.; Rozen, S.G.; Tan, P.; Epstein, D.M. A tumor-associated splice-isoform of MAP2K7 drives dedifferentiation in MBNL1-low cancers via JNK activation. Proc. Natl. Acad. Sci. USA 2020, 117, 16391-16400. [CrossRef] [PubMed]

43. Aebersold, D.M.; Shaul, Y.D.; Yung, Y.; Yarom, N.; Yao, Z.; Hanoch, T.; Seger, R. Extracellular signal-regulated kinase 1c (ERK1c), a novel 42-kilodalton ERK, demonstrates unique modes of regulation, localization, and function. Mol. Cell. Biol. 2004, 24, 10000-10015. [PubMed]

44. Sudo, T.; Yagasaki, Y.; Hama, H.; Watanabe, N.; Osada, H. Exip, a new alternative splicing variant of p38 alpha, can induce an earlier onset of apoptosis in HeLa cells. Biochem. Biophys. Res. Commun. 2002, 291, 838-843. [CrossRef]

45. Yagasaki, Y.; Sudo, T.; Osada, H. Exip, a splicing variant of p38alpha, participates in interleukin-1 receptor proximal complex and downregulates NF-kappaB pathway. FEBS Lett. 2004, 575, 136-140. [CrossRef] [PubMed]

46. Zervos, A.S.; Faccio, L.; Gatto, J.P.; Kyriakis, J.M.; Brent, R. Mxi2, a mitogen-activated protein kinase that recognizes and phosphorylates Max protein. Proc. Natl. Acad. Sci. USA 1995, 92, 10531-10534. [PubMed]

47. Sanz, V.; Arozarena, I.; Crespo, P. Distinct carboxy-termini confer divergent characteristics to the mitogen-activated protein kinase p38alpha and its splice isoform Mxi2. FEBS Lett. 2000, 474, 169-174. [PubMed]

48. Sanz-Moreno, V.; Casar, B.; Crespo, P. p38alpha isoform Mxi2 binds to extracellular signal-regulated kinase 1 and 2 mitogenactivated protein kinase and regulates its nuclear activity by sustaining its phosphorylation levels. Mol. Cell. Biol. 2003, 23, 3079-3090. [CrossRef] [PubMed]

49. Zeke, A.; Misheva, M.; Remenyi, A.; Bogoyevitch, M.A. JNK Signaling: Regulation and Functions Based on Complex ProteinProtein Partnerships. Microbiol. Mol. Biol. Rev. 2016, 80, 793-835. [CrossRef] [PubMed]

50. Gupta, S.; Barrett, T.; Whitmarsh, A.J.; Cavanagh, J.; Sluss, H.K.; Derijard, B.; Davis, R.J. Selective interaction of JNK protein kinase isoforms with transcription factors. EMBO J. 1996, 15, 2760-2770.

51. Park, J.Y.; Yun, Y.; Chung, K.Y. Conformations of JNK3alpha splice variants analyzed by hydrogen/deuterium exchange mass spectrometry. J. Struct. Biol. 2017, 197, 271-278. [CrossRef] [PubMed]

52. McCaw, B.J.; Chow, S.Y.; Wong, E.S.; Tan, K.L.; Guo, H.; Guy, G.R. Identification and characterization of mErk5-T, a novel Erk5/Bmk1 splice variant. Gene 2005, 345, 183-190. [CrossRef] [PubMed]

53. Chang, L.; Karin, M. Mammalian MAP kinase signalling cascades. Nature 2001, 410, 37-40. [PubMed]

54. Kuida, K.; Boucher, D.M. Functions of MAP kinases: Insights from gene-targeting studies. J. Biochem. 2004, 135, 653-656. [CrossRef]

55. Pages, G.; Guerin, S.; Grall, D.; Bonino, F.; Smith, A.; Anjuere, F.; Auberger, P.; Pouyssegur, J. Defective thymocyte maturation in p44 MAP kinase (Erk 1) knockout mice. Science 1999, 286, 1374-1377. [CrossRef] [PubMed]

56. Yao, Y.; Li, W.; Wu, J.; Germann, U.A.; Su, M.S.; Kuida, K.; Boucher, D.M. Extracellular signal-regulated kinase 2 is necessary for mesoderm differentiation. Proc. Natl. Acad. Sci. USA 2003, 100, 12759-12764. [CrossRef] [PubMed]

57. Hatano, N.; Mori, Y.; Oh-hora, M.; Kosugi, A.; Fujikawa, T.; Nakai, N.; Niwa, H.; Miyazaki, J.; Hamaoka, T.; Ogata, M. Essential role for ERK2 mitogen-activated protein kinase in placental development. Genes Cells 2003, 8, 847-856. [CrossRef]

58. Voisin, L.; Saba-El-Leil, M.K.; Julien, C.; Fremin, C.; Meloche, S. Genetic Demonstration of a Redundant Role of ERK1 and ERK2 MAP Kinases in Promoting Fibroblast Proliferation. Mol. Cell. Biol. 2010, 30, 2918-2932. [CrossRef]

59. Mazzucchelli, C.; Vantaggiato, C.; Ciamei, A.; Fasano, S.; Pakhotin, P.; Krezel, W.; Welzl, H.; Wolfer, D.P.; Pages, G.; Valverde, O.; et al. Knockout of ERK1 MAP kinase enhances synaptic plasticity in the striatum and facilitates striatal-mediated learning and memory. Neuron 2002, 34, 807-820. [CrossRef]

60. Dong, C.; Yang, D.D.; Wysk, M.; Whitmarsh, A.J.; Davis, R.J.; Flavell, R.A. Defective T cell differentiation in the absence of Jnk1. Science 1998, 282, 2092-2095. [CrossRef] [PubMed]

61. Yang, D.D.; Conze, D.; Whitmarsh, A.J.; Barrett, T.; Davis, R.J.; Rincon, M.; Flavell, R.A. Differentiation of CD4+ T cells to Th1 cells requires MAP kinase JNK2. Immunity 1998, 9, 575-585. [CrossRef]

62. Busca, R.; Pouyssegur, J.; Lenormand, P. ERK1 and ERK2 Map Kinases: Specific Roles or Functional Redundancy? Front. Cell. Dev. Biol. 2016, 4, 53. [CrossRef] [PubMed]

63. Cameron, S.J.; Abe, J.; Malik, S.; Che, W.; Yang, J. Differential role of MEK5alpha and MEK5beta in BMK1/ERK5 activation. J. Biol. Chem. 2004, 279, 1506-1512. [CrossRef]

64. English, J.M.; Vanderbilt, C.A.; Xu, S.; Marcus, S.; Cobb, M.H. Isolation of MEK5 and differential expression of alternatively spliced forms. J. Biol. Chem. 1995, 270, 28897-28902. [CrossRef] [PubMed]

65. Nishimoto, S.; Nishida, E. MAPK signalling: ERK5 versus ERK1/2. EMBO Rep. 2006, 7, 782-786. [CrossRef] [PubMed]

66. Haeusgen, W.; Tueffers, L.; Herdegen, T.; Waetzig, V. Map2k4delta - identification and functional characterization of a novel Map2k4 splice variant. Biochim. Biophys. Acta 2014, 1843, 875-884. [CrossRef] 
67. Derijard, B.; Raingeaud, J.; Barrett, T.; Wu, I.H.; Han, J.; Ulevitch, R.J.; Davis, R.J. Independent human MAP-kinase signal transduction pathways defined by MEK and MKK isoforms. Science Erratum in Science 1995, 269, 17. 1995, 267, $682-685$. [CrossRef] [PubMed]

68. Lawler, S.; Fleming, Y.; Goedert, M.; Cohen, P. Synergistic activation of SAPK1/JNK1 by two MAP kinase kinases in vitro. Curr. Biol. 1998, 8, 1387-1390. [CrossRef]

69. Ganiatsas, S.; Kwee, L.; Fujiwara, Y.; Perkins, A.; Ikeda, T.; Labow, M.A.; Zon, L.I. SEK1 deficiency reveals mitogen-activated protein kinase cascade crossregulation and leads to abnormal hepatogenesis. Proc. Natl. Acad. Sci. USA 1998, 95, 6881-6886. [CrossRef] [PubMed]

70. Haeusgen, W.; Herdegen, T.; Waetzig, V. The bottleneck of JNK signaling: Molecular and functional characteristics of MKK4 and MKK7. Eur. J. Cell Biol. 2011, 90, 536-544. [CrossRef] [PubMed]

71. Asaoka, Y.; Nishina, H. Diverse physiological functions of MKK4 and MKK7 during early embryogenesis. J. Biochem. 2010, 148, 393-401. [CrossRef] [PubMed]

72. Haeusgen, W.; Herdegen, T.; Waetzig, V. MKK7gamma1 reverses nerve growth factor signals: Proliferation and cell death instead of neuritogenesis and protection. Cell. Signal. 2011, 23, 1281-1290. [CrossRef] [PubMed]

73. Nakagawa, K.; Sugahara, M.; Yamasaki, T.; Kajiho, H.; Takahashi, S.; Hirayama, J.; Minami, Y.; Ohta, Y.; Watanabe, T.; Hata, Y.; et al. Filamin associates with stress signalling kinases MKK7 and MKK4 and regulates JNK activation. Biochem. J. 2010, 427, 237-245. [CrossRef]

74. Haeusgen, W.; Boehm, R.; Zhao, Y.; Herdegen, T.; Waetzig, V. Specific activities of individual c-Jun N-terminal kinases in the brain. Neuroscience 2009, 161, 951-959. [CrossRef] [PubMed]

75. Martinez, N.M.; Agosto, L.; Qiu, J.; Mallory, M.J.; Gazzara, M.R.; Barash, Y.; Fu, X.D.; Lynch, K.W. Widespread JNK-dependent alternative splicing induces a positive feedback loop through CELF2-mediated regulation of MKK7 during T-cell activation. Genes Dev. 2015, 29, 2054-2066. [CrossRef] [PubMed]

76. Barr, R.K.; Bogoyevitch, M.A. The c-Jun N-terminal protein kinase family of mitogen-activated protein kinases (JNK MAPKs). Int. J. Biochem. Cell Biol. 2001, 33, 1047-1063. [CrossRef]

77. Sabapathy, K.; Jochum, W.; Hochedlinger, K.; Chang, L.; Karin, M.; Wagner, E.F. Defective neural tube morphogenesis and altered apoptosis in the absence of both JNK1 and JNK2. Mech. Dev. 1999, 89, 115-124. [CrossRef]

78. Kuan, C.Y.; Yang, D.D.; Samanta Roy, D.R.; Davis, R.J.; Rakic, P.; Flavell, R.A. The Jnk1 and Jnk2 protein kinases are required for regional specific apoptosis during early brain development. Neuron 1999, 22, 667-676. [CrossRef]

79. Hu, M.C.; Qiu, W.R.; Wang, Y.P. JNK1, JNK2 and JNK3 are p53 N-terminal serine 34 kinases. Oncogene 1997, 15, 2277-2287. [CrossRef] [PubMed]

80. Liu, J.; Minemoto, Y.; Lin, A. c-Jun N-terminal protein kinase 1 (JNK1), but not JNK2, is essential for tumor necrosis factor alpha-induced c-Jun kinase activation and apoptosis. Mol. Cell. Biol. 2004, 24, 10844-10856. [CrossRef] [PubMed]

81. Sabapathy, K.; Hochedlinger, K.; Nam, S.Y.; Bauer, A.; Karin, M.; Wagner, E.F. Distinct roles for JNK1 and JNK2 in regulating JNK activity and c-Jun-dependent cell proliferation. Mol. Cell 2004, 15, 713-725. [CrossRef] [PubMed]

82. Amura, C.R.; Marek, L.; Winn, R.A.; Heasley, L.E. Inhibited neurogenesis in JNK1-deficient embryonic stem cells. Mol. Cell. Biol. 2005, 25, 10791-10802. [CrossRef] [PubMed]

83. Castro-Torres, R.D.; Landa, J.; Rabaza, M.; Busquets, O.; Olloquequi, J.; Ettcheto, M.; Beas-Zarate, C.; Folch, J.; Camins, A.; Auladell, C.; et al. JNK Isoforms Are Involved in the Control of Adult Hippocampal Neurogenesis in Mice, Both in Physiological Conditions and in an Experimental Model of Temporal Lobe Epilepsy. Mol. Neurobiol. 2019, 56, 5856-5865. [CrossRef] [PubMed]

84. Nakano, R.; Nakayama, T.; Sugiya, H. Biological Properties of JNK3 and Its Function in Neurons, Astrocytes, Pancreatic beta-Cells and Cardiovascular Cells. Cells 2020, 9, 1802. [CrossRef] [PubMed]

85. Nielsen, C.; Thastrup, J.; Bottzauw, T.; Jaattela, M.; Kallunki, T. c-Jun NH2-terminal kinase 2 is required for Ras transformation independently of activator protein 1. Cancer Res. 2007, 67, 178-185. [CrossRef] [PubMed]

86. Schumacher, M.; Schuster, C.; Rogon, Z.M.; Bauer, T.; Caushaj, N.; Baars, S.; Szabowski, S.; Bauer, C.; Schorpp-Kistner, M.; Hess, J.; et al. Efficient keratinocyte differentiation strictly depends on JNK-induced soluble factors in fibroblasts. J. Invest. Dermatol. 2014, 134, 1332-1341. [CrossRef] [PubMed]

87. Zhang, D.; Song, L.; Li, J.; Wu, K.; Huang, C. Coordination of JNK1 and JNK2 is critical for GADD45alpha induction and its mediated cell apoptosis in arsenite responses. J. Biol. Chem. 2006, 281, 34113-34123. [CrossRef]

88. Wang, P.; Xiong, Y.; Ma, C.; Shi, T.; Ma, D. Molecular cloning and characterization of novel human JNK2 (MAPK9) transcript variants that show different stimulation activities on AP-1. BMB Rep. 2010, 43, 738-743. [CrossRef] [PubMed]

89. Yang, J.Y.; Moulin, N.; van Bemmelen, M.X.; Dubuis, G.; Tawadros, T.; Haefliger, J.A.; Waeber, G.; Widmann, C. Splice variantspecific stabilization of JNKs by IB1/JIP1. Cell. Signal. 2007, 19, 2201-2207. [CrossRef] [PubMed]

90. Enslen, H.; Raingeaud, J.; Davis, R.J. Selective activation of p38 mitogen-activated protein (MAP) kinase isoforms by the MAP kinase kinases MKK3 and MKK6. J. Biol. Chem. 1998, 273, 1741-1748. [CrossRef] [PubMed]

91. Keesler, G.A.; Bray, J.; Hunt, J.; Johnson, D.A.; Gleason, T.; Yao, Z.; Wang, S.W.; Parker, C.; Yamane, H.; Cole, C.; et al. Purification and activation of recombinant p38 isoforms alpha, beta, gamma, and delta. Protein Expr. Purif. 1998, 14, 221-228. [CrossRef] [PubMed]

92. Remy, G.; Risco, A.M.; Inesta-Vaquera, F.A.; Gonzalez-Teran, B.; Sabio, G.; Davis, R.J.; Cuenda, A. Differential activation of p38MAPK isoforms by MKK6 and MKK3. Cell. Signal. 2010, 22, 660-667. [CrossRef] [PubMed] 
93. Galan-Moya, E.M.; de la Cruz-Morcillo, M.A.; Llanos Valero, M.; Callejas-Valera, J.L.; Melgar-Rojas, P.; Hernadez Losa, J.; Salcedo, M.; Fernandez-Aramburo, A.; Ramon y Cajal, S.; Sanchez-Prieto, R. Balance between MKK6 and MKK3 mediates p38 MAPK associated resistance to cisplatin in NSCLC. PLoS ONE 2011, 6, e28406. [CrossRef] [PubMed]

94. Brancho, D.; Tanaka, N.; Jaeschke, A.; Ventura, J.J.; Kelkar, N.; Tanaka, Y.; Kyuuma, M.; Takeshita, T.; Flavell, R.A.; Davis, R.J. Mechanism of p38 MAP kinase activation in vivo. Genes Dev. 2003, 17, 1969-1978. [CrossRef] [PubMed]

95. Tanaka, N.; Kamanaka, M.; Enslen, H.; Dong, C.; Wysk, M.; Davis, R.J.; Flavell, R.A. Differential involvement of p38 mitogenactivated protein kinase kinases MKK3 and MKK6 in T-cell apoptosis. EMBO Rep. 2002, 3, 785-791. [CrossRef] [PubMed]

96. Chen, Y.; Shi, G.; Xia, W.; Kong, C.; Zhao, S.; Gaw, A.F.; Chen, E.Y.; Yang, G.P.; Giaccia, A.J.; Le, Q.T.; et al. Identification of hypoxia-regulated proteins in head and neck cancer by proteomic and tissue array profiling. Cancer Res. 2004, 64, 7302-7310. [CrossRef] [PubMed]

97. Cuenda, A.; Rousseau, S. p38 MAP-kinases pathway regulation, function and role in human diseases. Biochim. Biophys. Acta 2007, 1773, 1358-1375. [CrossRef] [PubMed]

98. Goedert, M.; Cuenda, A.; Craxton, M.; Jakes, R.; Cohen, P. Activation of the novel stress-activated protein kinase SAPK4 by cytokines and cellular stresses is mediated by SKK3 (MKK6); comparison of its substrate specificity with that of other SAP kinases. EMBO J. 1997, 16, 3563-3571. [CrossRef]

99. Goedert, M.; Hasegawa, M.; Jakes, R.; Lawler, S.; Cuenda, A.; Cohen, P. Phosphorylation of microtubule-associated protein tau by stress-activated protein kinases. FEBS Lett. 1997, 409, 57-62. [CrossRef]

100. Gupta, J.; Nebreda, A.R. Roles of p38alpha mitogen-activated protein kinase in mouse models of inflammatory diseases and cancer. FEBS J 2015, 282, 1841-1857. [CrossRef] [PubMed]

101. Beardmore, V.A.; Hinton, H.J.; Eftychi, C.; Apostolaki, M.; Armaka, M.; Darragh, J.; Mcllrath, J.; Carr, J.M.; Armit, L.J.; Clacher, C.; et al. Generation and characterization of p38beta (MAPK11) gene-targeted mice. Mol. Cell. Biol. 2005, 25, 10454-10464. [CrossRef] [PubMed]

102. Sabio, G.; Arthur, J.S.; Kuma, Y.; Peggie, M.; Carr, J.; Murray-Tait, V.; Centeno, F.; Goedert, M.; Morrice, N.A.; Cuenda, A. p38gamma regulates the localisation of SAP97 in the cytoskeleton by modulating its interaction with GKAP. EMBO J. 2005, 24, 1134-1145. [CrossRef] [PubMed]

103. Faccio, L.; Chen, A.; Fusco, C.; Martinotti, S.; Bonventre, J.V.; Zervos, A.S. Mxi2, a splice variant of p38 stress-activated kinase, is a distal nephron protein regulated with kidney ischemia. Am. J. Physiol. Cell Physiol. 2000, 278, C781-C790. [CrossRef] [PubMed]

104. Casar, B.; Sanz-Moreno, V.; Yazicioglu, M.N.; Rodriguez, J.; Berciano, M.T.; Lafarga, M.; Cobb, M.H.; Crespo, P. Mxi2 promotes stimulus-independent ERK nuclear translocation. EMBO J. 2007, 26, 635-646. [CrossRef] [PubMed]

105. Casar, B.; Rodriguez, J.; Gibor, G.; Seger, R.; Crespo, P. Mxi2 sustains ERK1/2 phosphorylation in the nucleus by preventing ERK1/2 binding to phosphatases. Biochem. J. 2012, 441, 571-578. [CrossRef] [PubMed]

106. KÖditz, B.; Fries, J.W.U.; GÖbel, H.; Paffenholz, P.; Richter, K.; Heidenreich, A.; Von Brandenstein, M. Mxi-2 Dependent Regulation of p53 in Prostate Cancer. Anticancer Res. 2020, 40, 5539-5544. [CrossRef]

107. Carbonell, C.; Ulsamer, A.; Vivori, C.; Papasaikas, P.; Bottcher, R.; Joaquin, M.; Minana, B.; Tejedor, J.R.; de Nadal, E.; Valcarcel, J.; et al. Functional Network Analysis Reveals the Relevance of SKIIP in the Regulation of Alternative Splicing by p38 SAPK. Cell Rep. 2019, 27, 847-859. [CrossRef] [PubMed]

108. O'Brien, D.E.; Alter, B.J.; Satomoto, M.; Morgan, C.D.; Davidson, S.; Vogt, S.K.; Norman, M.E.; Gereau, G.B.; Demaro, J.A., 3rd; Landreth, G.E.; et al. ERK2 alone drives inflammatory pain but cooperates with ERK1 in sensory neuron survival. J. Neurosci. 2015, 35, 9491-9507. [CrossRef] [PubMed]

109. Bar-Gill, A.B.; Efergan, A.; Seger, R.; Fukuda, M.; Sagi-Eisenberg, R. The extra-cellular signal regulated kinases ERK1 and ERK2 segregate displaying distinct spatiotemporal characteristics in activated mast cells. Biochim. Biophys. Acta 2013, 1833, $2070-2082$ [CrossRef]

110. Guegan, J.P.; Ezan, F.; Theret, N.; Langouet, S.; Baffet, G. MAPK signaling in cisplatin-induced death: Predominant role of ERK1 over ERK2 in human hepatocellular carcinoma cells. Carcinogenesis 2013, 34, 38-47. [CrossRef]

111. Von Thun, A.; Birtwistle, M.; Kalna, G.; Grindlay, J.; Strachan, D.; Kolch, W.; von Kriegsheim, A.; Norman, J.C. ERK2 drives tumour cell migration in three-dimensional microenvironments by suppressing expression of Rab17 and liprin-beta2. J. Cell Sci. 2012, 125, 1465-1477. [CrossRef]

112. Shin, S.; Dimitri, C.A.; Yoon, S.-O.; Dowdle, W.; Blenis, J. ERK2 but Not ERK1 Induces Epithelial-to-Mesenchymal Transformation via DEF Motif-Dependent Signaling Events. Mol. Cell 2010, 38, 114-127. [CrossRef] [PubMed]

113. Liu, X.; Yan, S.; Zhou, T.; Terada, Y.; Erikson, R.L. The MAP kinase pathway is required for entry into mitosis and cell survival. Oncogene 2004, 23, 763-776. [CrossRef] [PubMed]

114. Yu, S.; Zhang, M.; Huang, L.; Ma, Z.; Gong, X.; Liu, W.; Zhang, J.; Chen, L.; Yu, Z.; Zhao, W.; et al. ERK1 indicates good prognosis and inhibits breast cancer progression by suppressing YAP1 signaling. Aging 2019, 11, 12295-12314. [CrossRef]

115. Crowe, M.S.; Zavorotinskaya, T.; Voliva, C.F.; Shirley, M.D.; Wang, Y.; Ruddy, D.A.; Rakiec, D.P.; Engelman, J.A.; Stuart, D.D.; Freeman, A.K. RAF-mutant melanomas differentially depend on ERK2 over ERK1 to support aberrant MAPK pathway activation and cell proliferation. Mol. Cancer Res. 2021, 6, 1063-1075. [CrossRef] [PubMed]

116. Marchi, M.; D'Antoni, A.; Formentini, I.; Parra, R.; Brambilla, R.; Ratto, G.M.; Costa, M. The N-terminal domain of ERK1 accounts for the functional differences with ERK2. PLOS ONE 2008, 3, e3873. [CrossRef] 
117. Indrigo, M.; Papale, A.; Orellana, D.; Brambilla, R. Lentiviral vectors to study the differential function of ERK1 and ERK2 MAP kinases. Methods Mol. Biol. 2010, 661, 205-220. [CrossRef] [PubMed]

118. Boulton, T.G.; Nye, S.H.; Robbins, D.J.; Ip, N.Y.; Radziejewska, E.; Morgenbesser, S.D.; DePinho, R.A.; Panayotatos, N.; Cobb, M.H.; Yancopoulos, G.D. ERK's: A family of protein-serine/threonine kinases that are activated and tyrosine phosphorylated in response to insulin and NGF. Cell 1991, 65, 663-675. [CrossRef]

119. Gonzalez, F.A.; Raden, D.L.; Rigby, M.R.; Davis, R.J. Heterogeneous expression of four MAP kinase isoforms in human tissues. FEBS Lett. 1992, 304, 170-178. [CrossRef]

120. Shaul, Y.D.; Seger, R. ERK1c regulates Golgi fragmentation during mitosis. J. Cell Biol. 2006, 172, 885-897. [CrossRef] [PubMed]

121. Zheng, C.F.; Guan, K.L. Properties of MEKs, the kinases that phosphorylate and activate the extracellular signal-regulated kinases. J. Biol. Chem. 1993, 268, 23933-23939. [CrossRef]

122. Seger, R.; Krebs, E.G. The MAPK signaling cascade. FASEB J. 1995, 9, 726-735. [CrossRef]

123. Wortzel, I.; Hanoch, T.; Porat, Z.; Hausser, A.; Seger, R. Mitotic Golgi translocation of ERK1c is mediated by a PI4KIIIbeta-14-33gamma shuttling complex. J. Cell Sci. 2015, 128, 4083-4095. [CrossRef]

124. Wortzel, I.; Koifman, G.; Rotter, V.; Seger, R.; Porat, Z. High Throughput Analysis of Golgi Structure by Imaging Flow Cytometry. Sci. Rep. 2017, 7, 788. [CrossRef]

125. Wortzel, I.; Maik-Rachline, G.; Yadav, S.S.; Hanoch, T.; Seger, R. Mitotic HOOK3 phosphorylation by ERK1c drives microtubuledependent Golgi destabilization and fragmentation. iScience 2021, 24, 102670. [CrossRef] 